\title{
FRAMING THE REACTION OF PRESIDENT ABBAS ON THE ISSUE OF MOVING THE US EMBASSY FROM TEL AVIV TO JERUSALEM
}

\author{
Mohammed Fadel Arandas, Chang Peng Kee, Emma Mirza Wati Mohamad \& \\ Syed Arabi Idid
}

\begin{abstract}
The study has examined the similarities and differences in the coverage of two Palestinian news agencies Ma'an and Palestinian Information Center (PIC) on the reactions of Palestinian President Mahmoud Abbas's regarding relocating the US embassy from Tel Aviv to Jerusalem. The study has also aimed to explore the use of four function of framing by Entman 1993 in the news stories of both agencies. Qualitative content analysis has been adopted to achieve the aim of this study. The total sampling number was 9 news stories; 3 stories have been retrieved from Ma'an, and the other 6 have been retrieved from PIC. The time frame has started from December 5, 2017 which marked the day of informing Abbas by Trump's decision to move the Embassy until December 222017 which was a day after gaining a sweeping victory in UN by President Abbas through a resolution that rejected the decision. Both of the news agencies were supportive to President Abbas in their coverage and none of them has any negative coverage about him. From the sampling number it can be seen that PIC has paid more attention for the coverage of this issue than Ma'an. However, PIC has ignored the success of President Abbas for achieving UN resolution against Trump's decision. Morover, all the news stories has included "define the problem" while excluded "diagnose causes" functions. However both "make moral judgment" and "suggest remedies" have been included in all news stories of Ma'an, and only half of news stories of PIC.
\end{abstract}

Keywords: Abbas, Trump, US embassy, Jerusalem, Palestine

\section{INTRODUCTION}

On 1995 the US congress has adopted a law to move the US Embassy from Tel Aviv to Jerusalem and recognise Jerusalem as the capital of Israel starting from May 1999 (ACRPS, 2017; Al Jazeera Center for Studies, 2017; Arnaout, 2017; \& Mark, 1999). However, US presidents have been authorised to waive this law for 6-month periods if there is a necessity for it especially for national security interests. Since 1999 Presidents Clinton, George W Bush, and Obama did not implement the congress decision and have repeatedly signed that waiver to postpone implementing that decision (Al Jazeera Center for Studies, 2017; Arnaout, 2017; \& Mark, 1999).

Similar to his predecessors, President Donald Trump has signed the six-month waiver to postpone moving the Embassy to Jerusalem. However, after the expiry of his first postpone decision, trump has rejected to sign another postpone and decided to fulfil his promise to move the Embassy from Tel Aviv to Jerusalem (ACRPS, 2017; Al Jazeera Center for Studies, 2017; \& Arnaout, 2017). 
Trump has announced on Wednesday, December 6, 2017 his decision of officially recognising Jerusalem as capital of Israel, and declared his plans of moving the U.S. Embassy from Tel Aviv to Jerusalem. Then he has directed the State Department to begin of the process of establishing the embassy building in Jerusalem (Al Jazeera Center for Studies, 2017; ACRPS, 2017; BESA, 2017; Feldman \& Shikaki 2018). However, this decision has broken the traditions of US foreign policy on Jerusalem, which has avoided the declaration of Jerusalem as the capital of Israel for several decades (Al Jazeera Center for Studies, 2017 \& ACRPS, 2017).

This decision has defied the opposition and denunciation from several countries around the world including United Nation, all Arab \& Islamic countries, and several European countries (BESA, 2017 \& Feldman \& Shikaki 2018). Trump's decision has weakened the role of United States as neutral mediator in peace process, and ended the hopes of Palestinian Authority regarding the American role in the Middle East (Al Jazeera Center for Studies, 2017). This announcement has supported the illegal Israeli procedures under international law such as annexing Jerusalem into Israel, and accelerating building of settlement in the occupied Palestine (Husseini, 2017)

Recently, rapid developments have been occurred regarding the Middle East peace process which might affect the whole region. Several newsworthy events have taken a place in most of media channels in the world regarding Jerusalem issue especially after the decision of Trump for moving the US Embassy.

Hence, it is unknown how Palestinian media has covered this issue, and that has encouraged the researchers to explore that. Both and Ma'an News Agency and Palestinian Information Center (PIC) have covered the reactions of Palestinian President Mahmoud Abbas on moving the US Embassy from Tel Aviv to Jerusalem. This study has analysed the coverage of the two news agencies through qualitative aspect and it has been grounded on framing theory to show how this issue has been covered.

The significance of this study is reflected in contributing to the existed knowledge in framing, public diplomacy, and foreign policy through examining the coverage of Palestinian media on this significant contemporary conflict. Additionally, understanding this issue is critical since the media thought has an influence on the perception of the public and might affect the bilateral relations between Palestine and US.

\section{RESEARCH QUESTIONS}

In line with the main objective of the study, this study poses the following questions to be answered:

1. How do Palestinian media portrayed/framed the reaction of President Abbas regarding moving the embassy issue?

2. What framing functions of Entman have been used to cover this issue of moving the embassy?

\section{LITERATURES}

Recently, a growing attention has been paid to the framing issue especially that related to public diplomacy, foreign policy, public opinion, and bilateral relations between governments. 
When the national interest of one country is threatened widely by the American policies, then the public of that country might reject the sophisticated initiatives of American public diplomacy. If American Presidents have no ability of controlling the framing of their foreign policy in their own country media, so for sure they are going to face more difficulties with the media of other countries. Almost on principle, a lot of these nations are against the United States, and many other nations are neutral to doubt. It is not easy to conceive the parity in the treatment of the media of foreign country where the favoured framing of that country mostly clashes with the favoured framing by the American government (Entman, 2008).

The importance of understanding the mediated public diplomacy is reflected in the role of media framing though having strong influence on the support of public for peace and war (Sheafer, Shenhav, Takens \& van Atteveldt, 2014). The significance of the role played by media framing in public diplomacy is reflected in the definition of mediated public diplomacy by Entman (2008) as organised effort by president and his government including the apparatus of his foreign policy to create as much control as they can over framing the way of their policy in foreign media.

Additionally, Sheafer and Shenhav (2009) have discussed the role of frame building in mediated public diplomacy. When two countries have strong cultural ties between each other, so their government can push its own frames into the media of the other country thus it can improve its image among the public of the other country.

The way of perceiving the consequences, causes and importance of conflicts with foreign countries is determined by media framing of that conflict where material and diplomatic resources are obligated. Framing is appeared in other things such as the media coverage amount of specific conflict, and the language used for describing the events and actors in that conflict (Evans, 2010). The outlets of news are playing an important role in shaping the public opinion through applying frames of media, which use some tool such as structure, language, image, and style to affect the perception of public (Steele, 2014).

However, online public opinion is playing a significant role in shifting the original local event to become a prominent national issue. Online public opinion also has a significant influence of frame building in the early coverage stage on the subsequent reports of media (Zhou \& Moy, 2007). The media is playing significant role in the peace process. Media framing of peace and security issues has central impact on public opinion regarding peace (Sheafer \& Dvir-Gvirsman, 2010).

Since 1970s several researches have been examined framing issue which has discussed by psychologist Gregory Bateson (1972) and sociologist Erving Goffman (1974) and then by communication scholars such as Tuchman (1978) and then Entman (1993). The concept of framing bias and framing theory are suggesting how a topic is presented, how it affects the making choices by people. This idea is significant since it is opposite to the major concept of theory of rational choice, when people always try always for making the most rational options possible (Stack, 2013).

The use of word 'frame' can be as verb (to frame) or as noun (a frame). As a noun frame plays a filtering role in understanding, interpretation, and perception of specific situations. The verb refers to creating of a frame, whether intentionally or not, during communication. Based on the context, the verb may be used to manipulate, conceptualize, interpret, and persuade (Shmueli, 2008).

It is not surprising that the theory of framing has finally achieved its place in the research of mass communication, since the main objective of developing the frame concept was for explaining how pubic interpret, perceive, and understand reality. When public have no 
information about one event, then mass media present that events to public and influence their understanding and perception of it (Gamreklidze, 2015).

Framing has been used to examine communication is in a several disciplines including, media studies, psychology, health communication political communication, speech communication, organizational decision making, and economics (Hallahan, 1999).

Linking to socially constructed meanings, information processing, linguistic cues, and message patterns, frames and reframing are important to support the discourse of several geographical conflicts and to negotiating their resolutions. Knowing the construction and used frames may be helpful for understanding the dynamics of conflict or issue, and affect them to help stakeholders and for avoiding the negative consequences through finding new ways out of deadlock (Shmueli, 2008).

The media is playing a significant role during conflicts and wars time. Media ensures the knowledge of its public about an event through carrying the messages to it in conflicts and wars period. Mostly, the contents of those messages help the public to develop specific feelings and views about conflict and war. The long term Palestinian- Israeli conflict is considered one of the most long ongoing conflicts. The reflection and representation for this conflict is in the content of several media. This conflict has become subject to several number of academic studies (Sahin, 2017).

In communication field, several studies and researches have been conducted regarding the Palestinian-Israeli conflict. However, most of these studies have focused on media framing whether in American media, or on the Israeli perspective of Arabs, but this study tried to fill the gap of literature through examining mainstream Palestinian media sources to support the Palestinian perspective (Steele, 2014).

The Palestinian- Israeli conflict has been kept for decades alternately cooling down and heating up but never has a true solution. And over the years, the Middle East conflict is considered as emotional conflict with ongoing media bias allegations on both sides. The topic of conflict in important to media as the world become more interconnected and there has been dramatically influence by international communication such as satellite, Internet, and other technologies. Opposing sides knew how to use the media and manipulate their own to achieve spur action and international support such as humanitarian and military aides (Stawicki, 2009).

Mostly, people mentally project upon circumstances and their experiences the interpretive frames that allow them for making sense of their reality or surroundings in relation to themselves. They then have awareness on the regularly used frames when some necessity pushes them to integrate or replace one frame with another (Wendland, 2010).

Entman (1993) has discussed four functions of framing that have been used as the basis of this study. Those factions are: define problems or issues, identify the cause of problem through attributing the responsibility, making moral judgement, and suggesting remedies or solution for the problem. One sentence might include all the four functions, although some sentenced might not include any of them. Also, it is not necessary for a particular text to include those four factions.

\section{METHODOLOGY}

A human qualitative content analysis was carried out in this study. The qualitative aspect of this study has looked at the language used, and how two Palestinian news agencies have framed the reaction of President Abaas on moving the US embassy issue. The study also aimed to explore the used framing functions by Entman 1993 in the news stories about the issue of study. 
The population of the current study was both Ma'an News Agency and Palestinian Information Centre. According to its website, Ma'an News Agency has been launched in 2005 which is publishing in both Arabic and English. It also considered as one of the most browsed websites in Palestine. The website also stated that Ma'an Network is the largest online media, radio and TV group in Palestine. And through its Ma'an-Mix channel, it has regionally broadcasting satellite. According the website of Palestinian Information Center has been established in 1997 which mainly covers the Palestinian events in a several languages. The material of this news agency is published by on spot reporters, editors, correspondents, political analysts, and multi-lingual translators.

However, such as most of the Palestinian news websites, both of those news agencies websites have claimed that they are independent news agencies. However, it is very well known among the Palestinian public that Ma'an news agency is pro-government. In contrast, Palestinian Information Center (PIC) is owned by Hamas the rival of government.

Words such as "Abbas" \& "Trump" have been used as keyword search from December 52017 to December 22 2017. Only the relevant news stories have been chosen, and the unrelated stories have been dropped from the sample. A total sample of nine news stories have been retrieved and analysed from two news agencies, three stories were from Ma'an news agency, while the other six stories were from PIC. December 52017 has marked the day that Trump notified Abbas of his intention to relocate the US embassy to Jerusalem. December 22 2017 was a day after the UN resolution that rejected recognising Jerusalem as the capital of Israel by US.

\section{FINDINGS}

This study has shown the role of two national Palestinian news agencies Ma'an and PIC and analysed their role regarding Trump's decision to move the US embassy to Jerusalem and recognising it as a capital of Israel.

The total number of retrieved news stories from both news agencies was nine news stories from the period December 5, 2017 to December 23, 2018. Six out of nine news stories have been retrieved from PIC, and the other three news stories have been retrieved from Ma'an.

The results have revealed some similarities and differences in reporting and framing the issue of moving US embassy by both news agencies. Regarding the first research question, it can be seen that the coverage size of news stories by PIC was double converge of Ma'an which shows that PIC has paid more attention to cover this issue.

Another interesting finding was that both the Ma'an and PIC were supportive to Palestinian President Mahmoud Abbas in covering his news and speeches regarding moving the embassy issue. PIC, the rival of Abbas did not mention any negative tone/ slant about him; it has also quoted most of his speeches that supported the Palestinian point of view against the American step.

Both of these agencies have started their coverage on December 5, 2017 which was the first day of informing Abbas by Trump about his intention to relocate the US embassy to Jerusalem. Starting the coverage of this issue immediately after Trump's notification reflects the huge attention that has been paid to this issue by Palestinian media.

The sequence of publishing the three news stories by Ma'an was on December 5, 6, \& 22 while for PIC it was on December, 5, 6, 12, 13, 18, \&20 2017. From the publishing date, we can understand that PIC has ignored the success President Abbas who has gained a sweeping vote on a resolution in the UN on December 21that rejected the decision of Trump. 
Ignoring the success of President Abbas by PIC might be due the political conflict with Abbas, which open the question why Hamas owned media did not set this case in its agenda.

Regarding the second research question, all the news stories have been analysed through qualitative perspective after reading all the stories carefully. All these stories from both Ma'an and PIC have been included more than one framing function of Entman.

\section{Ma'an News Agency}

The study has started with analysing the three news stories from Ma'an news agency as following:

(1) The first news story on December 5, has included three functions out of four, namely define issue/problem, make moral judgment, and suggest solutions, while diagnose cause did not included. Defining the issue/ problem was as moving the US embassy. Ma'an has reported:

"Trump tells Abbas of plans to move embassy as world leaders warn of consequences". \& "After days of speculation over whether the US would be moving its Israeli embassy from Tel Aviv to Jerusalem, American President Donald Trump called Palestinian President Mahmoud Abbas on Tuesday and confirmed his intentions to move the embassy".

Making moral judgment which was the second used function showed opposition and condemnation of Trump's step since it is dangerous for peace, which has mentioned in the next paragraphs:

"Abbas warned Trump of the dangerous repercussions of such step for the peaceprocess between Israel and Palestine, and for general security and stability in the region and world"; "Trump's decision has drawn condemnation from leaders across the globe, including Palestine, Jordan, Egypt, Turkey, Saudi Arabia, Germany, France, and the EU"; \& "According to Haaretz, 25 former Israeli ambassadors, academics and peace activists also expressed their opposition to Trump's potential recognition of Jerusalem as Israel's capital in a letter to Trump's envoy in the region, Jason Greenblatt".

Suggesting solution was the third used function discussed contacting the world leaders for preventing moving the embassy step:

"Abu Rudeineh stressed that Abbas "will continue to contact world leaders in order to prevent this unacceptable."

(2) The second news story has also included the same three functions that have been used in the first news story as defining issue, making moral judgment, and suggesting solutions. The issue has been identified as moving the embassy to Jerusalem and recognising it as the capital of Israel. The next paragraphs elaborated about that:

"Abbas urges UN to stop Trump from recognizing Jerusalem as Israeli capital". The moral judgment function has explained that the US decision would end peace process as following:

"In his letter, Abbas said that "this would end the peace process," which Trump and his administration have attempted to revive in the first year of his presidency, with reports in recent weeks suggesting that the "ultimate peace plan" would be announced soon" \& "Israeli news daily Haaretz quoted Nabil Shaath, a senior Palestinian official, as saying that "the mother of all the [peace] deals dies here on the rocks in Jerusalem if he says tomorrow that he recognizes a united Jerusalem as the capital of Israel." 
Suggesting solutions function was through the pleading of Abbas to UN to stop the decision as following:

"Hours before US President Donald Trump is expected to announce his decision to move the American embassy in Tel Aviv to Jerusalem and recognized the Israelioccupied city as the official capital of Israel, Palestinian president Mahmoud Abbas, in a last-ditch-effort, is reportedly pleading to the United Nations (UN) to stop the move".

(3) As the other previous news storied, the third news story has also included the same three functions which are define issue, make moral judgment, and suggest solutions. The issue has been identified as recognition of Jerusalem as the capital of Israel. The next paragraphs elaborated about that:

"President Mahmoud Abbas Friday met with his French counterpart Emmanuel Macron at the Elysee Palace in Paris, where the two discussed ongoing developments in the region following a sweeping vote at the UN on Thursday in favour of rejecting US President Donald Trump's recognition of Jerusalem as the capital of Israel."

The moral judgment function that has been indicated in this news story was as support of Palestine by France:

"Abbas reportedly thanked Macron for his country's positions in support of Palestine, most recent of which was France's voting in favour of the UN draft resolution on Jerusalem."

Finally, suggesting solutions function was through rejecting the decision of Trump:

"President Mahmoud Abbas Friday met with his French counterpart Emmanuel Macron at the Elysee Palace in Paris, where the two discussed ongoing developments in the region following a sweeping vote at the UN on Thursday in favor of rejecting US President Donald Trump's recognition of Jerusalem as the capital of Israel."

\section{Palestinian Information Center}

The following six news stories have been retrieved from Palestinian Information Center (PIC) news agency:

(1) The first news story was on December 5, has included three functions which are defining issue/problem, making moral judgment, and suggesting solutions. The identified problem was moving the U.S. Embassy to Occupied Jerusalem. PIC has reported:

"U.S. President Donald Trump informed Palestinian President Mahmoud Abbas on Tuesday that he intends to move the U.S. Embassy to Occupied Jerusalem"; \& "Trump notified in a telephone call with Mahmoud Abbas of his intention to move the American embassy from Tel Aviv to Occupied Jerusalem, the Palestinian news agency WAFA reported."

The second function which was making moral judgment indicated as dangerous consequences of decision to peace process, which has mentioned in the next paragraphs:

“Abbas's spokesman Nabil Abu Rdainah said in a statement that President Abbas warned of the dangerous consequences such a decision would have to the peace process and to the security and stability of the region and of the world."

The third used function in the first news story was suggesting solutions through stressing that any future state must consider east Jerusalem as its capital: 
"There will be no Palestinian state without East Jerusalem as its capital in accordance with the international legitimacy resolutions and the Arab Peace initiative, Abbas was further quoted as stating."

(2) The second news story on December 6 has also included three same three that have been used in the previous news story. Defining the issue/ problem was declaring Jerusalem is the capital of Israel, PIC has reported:

"Palestinian President Mahmoud Abbas said on Wednesday that with U.S. President Donald Trump declaring that Jerusalem is the capital of Israel, he has chosen to disregard all international resolutions and to encourage Israel to tighten its policies of occupation, settlement, apartheid and ethnic cleansing"; "A few hours earlier, U.S. President Donald Trump has formally recognized Jerusalem as the capital of Israel, saying during his speech at the White House that he will move the U.S. embassy from Tel Aviv to Jerusalem, despite calls from the world leaders to backtrack on the move."

The second used function was making moral judgment through considering the decision of Trump as ethnic cleansing, and violating international\& bilateral resolution, which has mentioned in the next paragraphs:

"Abbas: Trump declaration on Jerusalem maximizes ethnic cleansing"; "The US administration has chosen to violate all international and bilateral resolutions and agreements, preferring to ignore and contradict the international consensus expressed by the positions of various countries, world leaders, spiritual leaders and regional organizations over the past few days on the subject of Jerusalem"; \& "These reprehensible measures constitute a deliberate undermining of all peace efforts and represent a declaration that the United States has withdrawn from playing the role it has played in the past decades in sponsoring the peace process," he added."

The third used function of framing was suggesting solutions through formulating appropriate decisions and procedures and restoring the Palestinian unity:

"The leadership is keeping up-to-date on the developments of the situation and is in the process of formulating appropriate decisions and procedures in consultation with neighbouring Arab and Muslim countries"; "This historic moment should serve as an additional incentive for all of us to accelerate and intensify efforts to end the division and restore Palestinian national unity to ensure the victory of our people in their struggle for freedom and independence"; \& "We will call on the Central Council of the Palestine Liberation Organization to hold an emergency session that all factions will be invited to in order to affirm the unified Palestinian national position and put all options before it."

(3) The third news story on December 12 has included only define issue/problem function which was recognition of Jerusalem as the capital of Israel:

"Palestinian Authority President Mahmoud Abbas on Tuesday met with his Turkish counterpart Recep Tayyip Erdogan before the emergency summit of the Organization of Islamic Conference (OIC) to discuss U.S. recognition of Jerusalem as the capital of Israel."

(4) The fourth news story on December 13 from PIC has included three functions which are defining issue/problem, making moral judgment, and suggesting solutions. Defining the issue/ problem function was recognition of Jerusalem as the capital of Israel that has been reported by PIC: 
"The Palestinian Authority (PA) president, Mahmoud Abbas, on Wednesday said that the Palestinian leadership will go to the UN Security Council (UNSC) to annul the US president Donald Trump's recognition of Jerusalem as the capital of Israel." The second used function was making moral judgment through considering US as unfit mediator for peace negotiations, which has mentioned in the next paragraphs:

"The PA president stressed that the US is no longer fit to serve as a mediator in the peace negotiations and called on the Muslim nations to intensify their visits to Jerusalem and support its people by all means."

Suggesting solutions was the third used function of framing was by going to UN Security Council for annulling Trump's decision:

"The Palestinian Authority (PA) president, Mahmoud Abbas, on Wednesday said that the Palestinian leadership will go to the UN Security Council (UNSC) to annul the US president Donald Trump's recognition of Jerusalem as the capital of Israel": \& "He noted that Palestinians will also go to the UNSC over full UN membership."

(5) The fifth news story on December 18 from PIC has included two functions of framing which are defining issue/problem and suggesting solutions. Defining the issue/ problem was taking the necessary steps against Trump's decision. PIC has reported:

"Abbas vowed to take all necessary steps, legal and diplomatic, against Trump's move, adding that the U.S. role as a peace broker has fallen apart. "“

The second used function was making moral judgment through considering these steps as strengthening the legal status of Palestine:

"Palestinian Authority (PA) President Mahmoud Abbas on Monday signed 22 agreements and international treaties that are believed to strengthen the legal status of the State of Palestine on a global scale."

(6) The sixth news story on December 20 has included only define issue/problem framing function as recognising Jerusalem as a capital of Israel. PIC has reported:

"Later, Abbas and Jubeir held a meeting to discuss US president Donald Trump's recognition of Occupied Jerusalem as Israel's capital and the possible ways to respond to such step."

\section{CONCLUSION}

This study has analysed news stories from two Palestinian news agencies Ma'an and PIC on the reaction of President Abbas regarding Trump's decision to relocate US from Tel Aviv to Jerusalem. The findings aimed to explore the similarities and differences between both news agencies in covering this issue. The findings also aimed to explore the used Entman's framing factions.

Only the related news stories to Abbas's reactions have been included, and the articles that did not mention President Abbas have been excluded. After identifying the sample, a qualitative content analysis has been used for a total of nine news stories; three from Ma'an and six from PIC within 18 days from December 5, 2017 to December 22, 2017.

The analysis has showed how both Palestinian news agencies have discussed moving the embassy issue, and has explained the similarities and differences in their coverage. Both of news agencies were supportive for President Arafat and did not include any negative coverage about him. The sampling number from both new agencies has revealed that the coverage of PIC was double the coverage of Ma'an which reflects that PIC gave more attention to this issue. 
However, PIC has ignored the achievement of President Abbas to have UN resolution that rejected the decision of trump.

Both of the news agencies have excluded diagnose causes from all news stories. However, Ma'an has framed four factions of Entman in a different way from PIC. Ma'an has included define problem, make moral judgment, and suggest remedies in all stories; PIC have only included define problem in all the news stories, and for make moral judgment, and suggest remedies it has included them in half of the stories.

The findings from the previous paragraphs open the question on the contradiction of PIC position once it has gave more coverage for Abbas, and another time it has ignored his achievement in UN. The other question is why Ma'an the pro-PLO agency did not pay enough attention and coverage for President Abbas within this crisis.

\section{REFERENCES}

Abbas, Erdogan discuss situation in Occupied Jerusalem. (2017, December 12). Palestinian Information Center. Retrieved January 18, 2018, from https://english.palinfo.com/news/2017/12/12/Abbas-Erdogan-discuss-situation-inOccupied-Jerusalem

Abbas in Riyadh to meet monarch and top officials. (2017, December 20, 07). Palestinian Information Center. https://english.palinfo.com/search/1-12-2017/1-132017/asc/2/abbas/true/false/false/false/false/false/1/

Abbas meets with French president in Paris. (2017, December 16). Ma'an News Agency. Retrieved January 18, 2018, from https://www.maannews.com/Content.aspx?id=779672

Abbas signs 22 int'l treaties to boost legal status of Palestine. (2017, December 18). Palestinian Information Center. Retrieved January 18, 2018, from https://english.palinfo.com/news/2017/12/18/Abbas-signs-22-int-1-treaties-to-boostlegal-status-of-Palestine

Abbas spokesman: We will not accept changes to 1967 East Jerusalem borders. (2017, December 16). Ma'an News Agency. Retrieved January 18, 2018, from https://www.maannews.com/Content.aspx?id=779641

Abbas: Trump declaration on Jerusalem maximizes ethnic cleansing. (2017, December 6). Palestinian Information Center. Retrieved January 18, 2018, from https://english.palinfo.com/news/2017/12/6/Abbas-Trump-declaration-on-Jerusalemmaximizes-ethnic-cleansing

Abbas urges UN to stop Trump from recognizing Jerusalem as Israeli capital. (2017, December 6). Ma'an News Agency. Retrieved January 18, 2018, from https://www.maannews.com/Content.aspx?id=779576

Abbas: We will go to UNSC to overturn Trump's decision. (2017, December 13). Palestinian Information Center. Retrieved January 18, 2018, from https://english.palinfo.com/news/2017/12/13/Abbas-We-will-go-to-UNSC-tooverturn-Trump-s-decision

Al Jazeera Center for Studies. (2017). Trump's recognition of Jerusalem as Israel's capital: Background and ramifications. Retrieved May 3, 2018 from http://studies.aljazeera.net/mritems/Documents/2017/12/25/4b95a54c599a4155987f7a f1b3999244_100.pdf 
Arab Center for Research and Policy Studies (ACRPS). (2017). Trump's decision to announce Jerusalem as the capital of Israel: motives, implications, and prospect. Retrieved May 3, 2018 from https://www.dohainstitute.org/en/Lists/ACRPSPDFDocumentLibrary/12\%20december\%20situation\%20assessment.pdf

Arnaout, A. A. (2017). The Time Bomb of Moving the U.S. Embassy to Jerusalem. Jerusalem Quarterly, 70, 23-26.

Azpíroz Manero, M. L. (2014). Framing and Political Discourse Analysis: Bush's Trip to Europe in 2005. Observatorio $\left(O B S^{*}\right), 8(3), 075-96$.

Bateson, G. (1972). Steps to an ecology of mind: Collected essays in anthropology, psychiatry, evolution, and epistemology. London, University of Chicago Press.

Baum, M. A., \& Potter, P. B. (2008). The relationships between mass media, public opinion, and foreign policy: Toward a theoretical synthesis. Annu. Rev. Polit. Sci., 11, 39-65.

Begin-Sadat Center for Strategic Studies (BESA). (2017). Trump's recognition of Jerusalem as Israel's capital- what does it mean?. Retrieved May 3, 2018 from https://besacenter.org/wp-content/uploads/2017/12/2-Jerusalem-Online-DebateFINAL-1.pdf

Entman, R.M. (1993). Framing: Toward clarification of a fractured paradigm. Journal of Communication, 43(4), 51-58.

Entman, R. M. (2008). Theorizing mediated public diplomacy: The US case. The International Journal of Press/Politics, 13(2), 87-102.

Evans, M. (2010). Framing international conflicts: Media coverage of fighting in the Middle East. International Journal of Media \& Cultural Politics, 6(2), 209-233.

Feldman, S., \& Shikaki, K. (2018). Trump's Jerusalem declaration and "the ultimate deal". Crown Center for Middle East Studies. Retrieved May 3, 2018 from https://www.brandeis.edu/crown/publications/meb/MEB114.pdf

Hallahan, K. (1999). Seven models of framing: Implications for public relations. Journal of public relations research, 11(3), 205-242.

Husseini, S. (2017). Moving US-Embassy to Jerusalem could be the straw that breaks the camel's back. Rosa Luxemburg Stiftung Regional Office Palestine. Retrieved May 3, 2018 from http://www.rosaluxemburg.ps/wp-content/uploads/2017/02/Sara-HusseiniPaper.pdf

Iyengar, S., \& Simon, A. (1993). News coverage of the Gulf crisis and public opinion: A study of agenda-setting, priming, and framing. Communication research, 20(3), 365-383.

Gamreklidze, E. (2015). Sourcing and framing analysis of source messages in the coverage of armed conflicts by American and British foreign reporters (Doctoral thesis). Louisiana State University.

Goffman, E. (1974). Frame analysis: An essay on the organization of experience. Harvard University Press.

Ma'an News Agency (MNA). About. Retrieved April 7, 2018 from http://www.maannews.com/About.aspx

Mark, C. (1999). Jerusalem: The U.S. Embassy and P.L. 104-45. Congressional Research Service The Library of Congress. Retrieved May 3, 2018 from https://fas.org/sgp/crs/mideast/RS20339.pdf

Noakes, J. A., \& Wilkins, K. G. (2002). Shifting frames of the Palestinian movement in US news. Media, Culture \& Society, 24(5), 649-671. 


\section{Vol. 15. No.5 (181-192), ISSN: 1823-884x}

Palestinian Information Center. About. Retrieved April 7, 2018 from https://english.palinfo.com/about-us

Sahin, M. (2017). An Examination of Academic Studies Covering Israel Palestine Conflict Over its Reflections Through Media. Online Journal of Communication and Media Technologies, 7(1), 1-14.

Sheafer, T., \& Dvir-Gvirsman, S. (2010). The spoiler effect: Framing attitudes and expectations toward peace. Journal of Peace Research, 47(2), 205-215.

Sheafer, T., \& Shenhav, S. R. (2009). Mediated public diplomacy in a new era of warfare. The Communication Review, 12(3), 272-283.

Sheafer, T., Shenhav, S. R., Takens, J., \& van Atteveldt, W. (2014). Relative political and value proximity in mediated public diplomacy: The effect of state-level homophily on international frame building. Political Communication, 31(1), 149-167.

Shmueli, D. F. (2008). Framing in geographical analysis of environmental conflicts: Theory, methodology and three case studies. Geoforum, 39(6), 2048-2061.

Stack, M. (2013). Sourcing and framing the'war on terror'. A study of attribution in elite newspaper coverage. PhD thesis, Dublin City University.

Stawicki, M. (2009). Framing the Israeli-Palestinian conflict: A study of frames used by three American newspapers. MA thesis, University of Missouri-Columbia.

Steele, K. (2014). Palestinian-Arab Media Frames and Stereotypes of Israeli-Jews. Elon Journal of Undergraduate Research in Communications, 5(1), 43-56.

Tidd, U., Mostafa, D., Brownlie, S., MOSTAFA, D. D., \& BROWNLIE, S. S. (2014). The Folktale as a Site of Framing Palestinian Memory and Identity in Speak, Bird, Speak Again and Qul Ya Tayer.

Trump notifies Abbas of intention to relocate embassy. (2017, December 5). Palestinian Information Center. Retrieved January 18, 2018, from https://english.palinfo.com/news/2017/12/5/Trump-notifies-Abbas-of-intention-torelocate-embassy

Trump tells Abbas of plans to move embassy as world leaders warn of consequences. (2017, December 5). Ma'an News Agency. Retrieved January 18, 2018, from https://www.maannews.com/Content.aspx?id=779571

Tuchman, G. 1978. Making news: A study in the construction of reality. New York: Free Press.

Wendland, E. R. (2010). Framing the Frames: A Theoretical Framework for the Cognitive Notion of "Frames of Reference.". Journal of Translation, 6(1), 27-50.

Zhou, Y., \& Moy, P. (2007). Parsing framing processes: The interplay between online public opinion and media coverage. Journal of communication, 57(1), 79-98.

\section{Authors:}

Mohammed Fadel Arandas ${ }^{1}$, Chang Peng Kee ${ }^{2}$ (Prof. Dr) \& Emma Mirza Wati Mohamad ${ }^{3}$ $(\mathrm{PhD})$

The National University Of Malaysia

Correspondence email: chang@ukm.edu.my

Syed Arabi Idid (PhD)

International Islamic University Malaysia 
